\title{
Anion Receptors with 2-Imidazolidone Molecular Scaffold
}

\author{
Hyungil Kim and Jongmin Kang* \\ Departmen of Chemistry, Sejong University, Seoul 143-747, Korea. "E-mail: kangm ájsejong.ac.kr \\ Received May 9, 2007
}

\begin{abstract}
Anion receptor based on 2-imidazolidone molecular scaffold has been synthesized. Anion binding studies carried out using 'H NMR and UV-vis spectroscopy revealed that this receptor 6 displays selectivity for the for the oxyanions such as acetate and dihydrogenphosphate ions and the affinity for the anions simply reflects the basicity of anions.
\end{abstract}

Key Words : Anion receptors, Ilydrogen bonding

\section{Introduction}

The development of new artilicial receptors for selective anion recognition is an area of intensive investigation owing to their importance in biomedicine and environment.' Many anions have diverse geometries that require shape-selective recognition. Therefore, many researchers have used hydrogen bonds as a recognition element as they are directional. The correct orientation of hydrogen bonds can differentiate between anionic guests with different geometries.

In nature, the hydrogen bonds are most often utilized to achieve anion binding by proteins. ${ }^{2}$ For cxample, antibiotic ristocetin utilizes three amide $\mathrm{N}-\mathrm{H}$ groups to form hydrogen bonds to the carboxylate anions." For synthetic receptors. hydrogen bonding groups are arranged through a space in a rigid and convergent manner. This has been achieved by incorporating hydrogen bonding group inside macrocycle ${ }^{4}$ or utilizing molecular scallold to arrange hydrogen bonding groups. Benzene rings, pyrtole, azulene" cyclohexane, cholic acid," 1ris(aminocthylamine) ${ }^{10}$ and calixarenes" have been utilized as molecular scaffolds to arrange hydrogen bonding groups.

To develop new anion receptors based on new molecular scaffold, we have designed the receptor 6 and 7 , which utilize 2-imidazolidone as a molecular scaffold.

2-Imidazolidone is a cyclicurea type molecule. The rigidity of the molecule provides solid molecular scaffold to arrange suitable binding moieties such as hydrogen bonds. Furthermore, the two amide $\mathrm{NH}$ groups in the molecule can be easily alkylated in basic condition to introduce binding groups.

The synthesis of the receptor 6 and 7 were achieved as depicted in Scheme 1. The synthesis started from the hydroxymethylation of 2-imidazolidone with paraformaldehyde under basic condition to give the compound $\mathbf{I}$. After the compound $\mathbf{I}$ was acetylated with acetic anhydride to give the compound 2 , the acetate group was substituted to chloride using thionyl chloride to give the compound 3 .

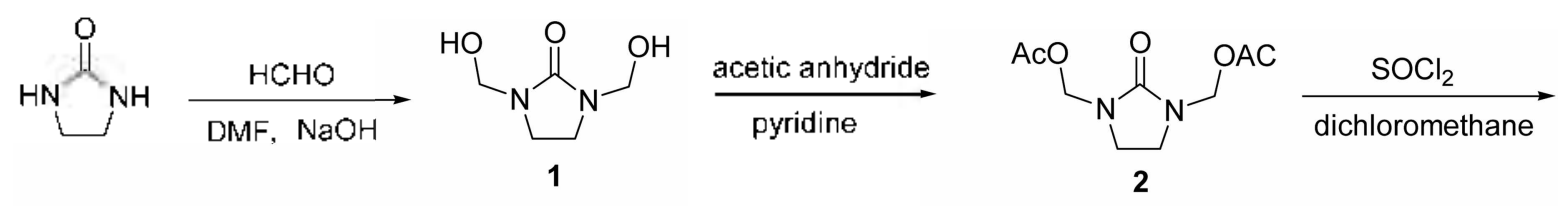<smiles>O=C1N(CCl)CCN1CCl</smiles>

3

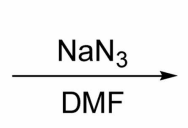

$30 \%$ four step
overall yield

6<smiles>NCN1CCN(CN)C1=O</smiles>

5

4-nitrobenzoylchloride dried DMF, $13 \%$<smiles>O=C(NCN1CCN(CNC(=O)c2ccc([N+](=O)[O-])cc2)C1=O)c1ccc([N+](=O)[O-])cc1</smiles>

7

Scheme 1 . The synthetic procedure for the anion receptors 6 and 7. 
Then, the compound 3 was transformed to the compound 4 with sodium azide. These four step reactions were performed without purification and the overall four step yield was $30 \%$. Hydrogenation of the compound $\mathbf{4}$ gave the diamine $\mathbf{5}$ in $83 \%$ yields. Finally, the reaction between 4-nitrophenylisocyanate and the compound 5 gave the desired product 6 in $27 \%$ yields. The product 7 was obtained from the reaction between the compound 5 and 4-nitrobenzoylchloride in $13 \%$ yields.

\section{Results and Discussion}

The complexation abilities of compounds 6 and 7 were measured by standard 'H NMR titration experiments in $10 \%$ DMSO in $\mathrm{CD}_{3} \mathrm{CN}$ using a constant host concentration (1.5-2 $\mathrm{mM}$ ) and increasing concentrations of anions ( $0.1-10$ equiv). 'The chemical shift data were analyzed by EQNMR. ${ }^{12}$ The addition of tetrabutylammonium anion salts to the solution of 6 in $10 \%$ DMSO in $\mathrm{CD}_{3} \mathrm{CN}$ resulted in downfield shifts in both of urea $\mathrm{N}-\mathrm{H}$ hydrogens. Therefore, the signals of these protons were used to determine the association constants for the compound 6 and anions. Whichever peaks we chose, binding constants between the receptor 6 and anions showed similar values. From the experiments, 6 showed the highest affinities for Y-shaped anions such as acetate and benzoate. The addition of tetrabutylammonium acetate or benzoate to the solution of 6 led downfield shifts of two N-H peaks in the urea. In the case of acetate, the two $\mathrm{N}-\mathrm{H}$ peaks in the urea moved from $6.84 \mathrm{ppm}$ to $10.15 \mathrm{ppm}$ and from $9.22 \mathrm{ppm}$ to 12.47 ppm respectively (Figure la). Job plot experiments showed $1: 1$ binding stoichiometry (Figure $2 a$ ) for acetate. The association constants calculated from ${ }^{\mathrm{l}} \mathrm{H}$ NMR titration gave $2.8 \times 10^{3} \pm 2.2 \times 10^{2}$ for acetate and $1.4 \times 10^{3} \pm 43$ for benzoate. The receptor also showed 1:l binding stoichiometry for the spherical halides and tetrahedral hydrogensulfate(Figure 2b). The association constants of spherical halides and tetrahedral anions along with $Y$ shaped anions from ${ }^{\mathrm{H}} \mathrm{H}$ NMR experiments are listed in lable $\mathrm{I}$. In the case of fluoride and dihydrogenphosphate, the $\mathrm{N}-\mathrm{H}$ peaks were disappeared as these anions were added to the solution of the receptor 6. Therefore, the binding properties of 6 with fluoride and dihydrogenphosphate were further assessed by UV-vis spectroscopy. Figure 2 shows the dependence of UVvis spectra of 6 on the concentration of fluoride in $10 \%$ DMSO in $\mathrm{CH}_{3} \mathrm{CN}$. Increasing the concentration of fluoride produced a bathochromic shift in the $\lambda_{\text {max }}$ from 337 to 354 nm (Figure 1b). Similar spectrum was observed for the titration of 6 with dihydrogenphosphate. The association constants calculated using a Benesi-Hildebrand plot $^{1.3}$ by use of change in the $\lambda_{m a}$, gave $5.8 \times 10^{2} \pm 27$ for fluoride and 1.1 $\times 10^{3} \pm 89$ for dihydrogenphosphate respectively. From the experiments, it is clear that the association constants reflect the basicity of anions. For example, among the halide investigated, the order of affinity to the receptor 6 was $\mathrm{F}^{-}>\mathrm{Cl}^{-}>\mathrm{Br}^{-}$. In addition, among the oxyanions, the order of affinity to the receptor 6 was $\mathrm{CH}_{3} \mathrm{CO}_{2}^{-}>\mathrm{H}_{2} \mathrm{PO}_{4}^{-}$ $\mathrm{C}_{6} \mathrm{H}_{3} \mathrm{CO}_{2}^{-}>\mathrm{NO}_{3}^{-}>\mathrm{HSO}_{4}^{-}$, which also reflect the basicity
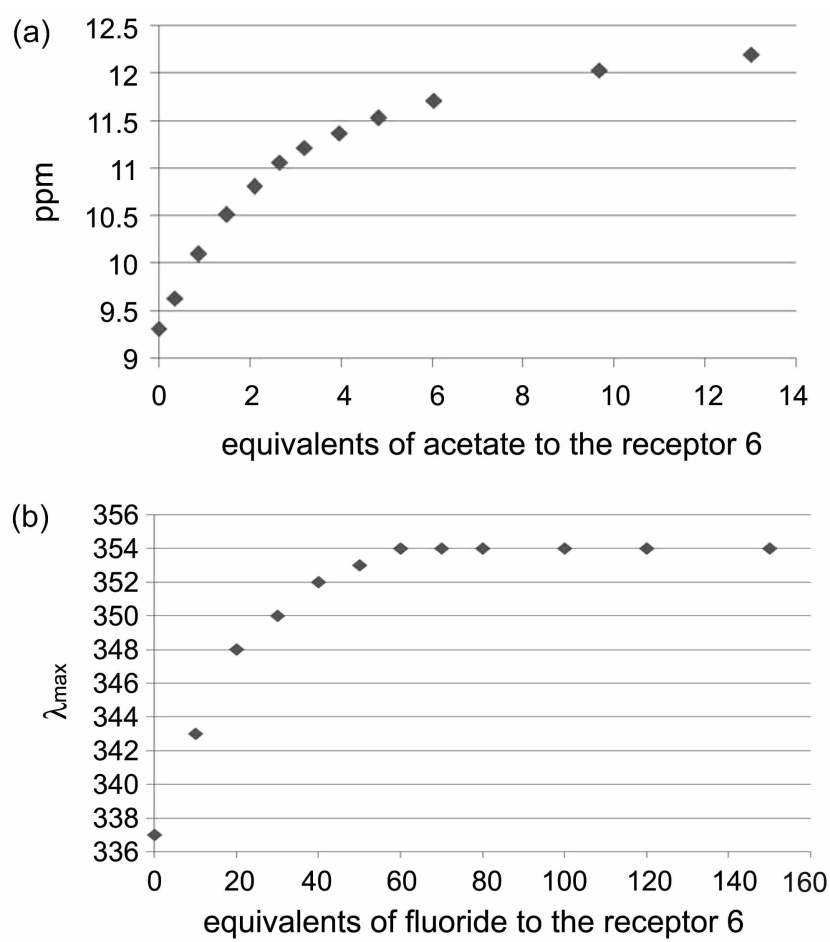

Figure 1. (a) Changes of the $\mathrm{X}-\mathrm{H}$ protons located in urea groups in 6 with increasing acetate concentrations. (b) Changes of $\lambda_{\text {max }}$ in 6 will increasing lluoride concentrations.
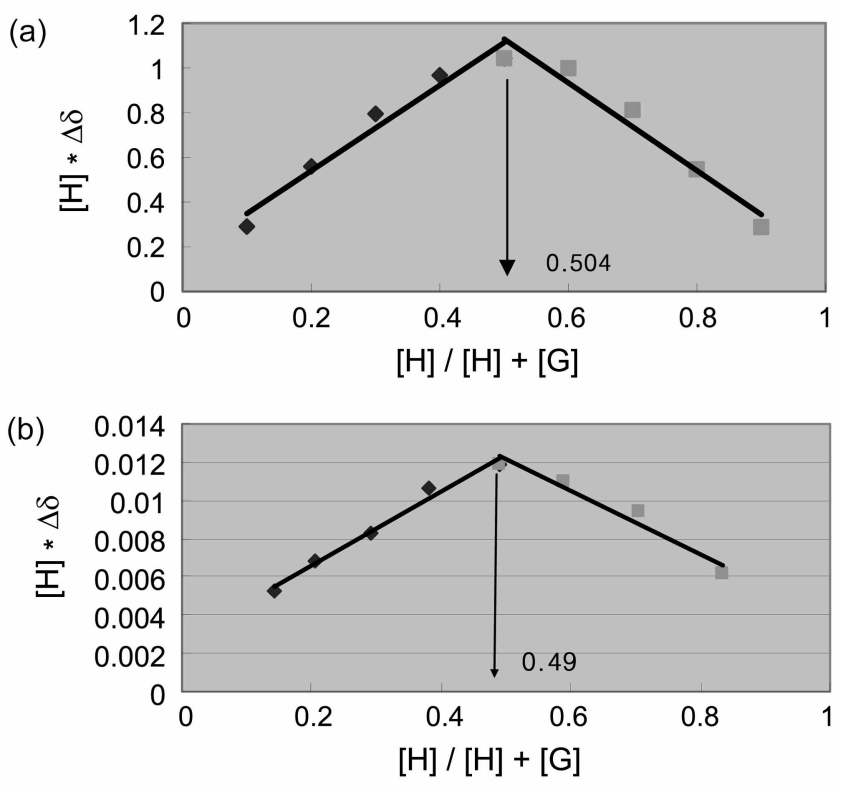

Figure 2. The Job plots of 6 with (a) tetrabutylammonium acetate. (b) tetrabuty lammonium hydrogensul late.

of oxyanions.

We also synthesized the receptor 7 which has two amide groups attached in 2-imidazolidone and investigated the associations of receptor 7 with various anions. However, only acetate, benzoate and dihydrogenphosphate bind weakly. The other anions investigated bind too weak to assess association constants. The results are also summarized in Table 1 . The possible binding mode of the receptor 
Table 1. Association constants $\left(\mathrm{M}^{-1}\right)$ of 6 and 7 with tetrabutylammonium anions in $10 \%$ DMSO-d $\mathrm{d}_{6}$ in $\mathrm{CD}_{3} \mathrm{C} . \mathrm{N}$. ${ }^{*}$ Association constants were calculated from UV-vis titration

\begin{tabular}{lll}
\hline Anion & \multicolumn{1}{c}{6} & 7 \\
\hline $\mathrm{F}^{-}$ & $5.8 \times 10^{2}-27^{*}$ & - \\
$\mathrm{Cl}^{-}$ & $3.4 \times 10^{2}-13$ & - \\
$\mathrm{Br}^{-}$ & $9.5 \times 10 \div 8$ & - \\
$\mathrm{NO}_{3}{ }^{-}$ & $3.2 \times 10^{2}-16$ & - \\
$\mathrm{HSO}_{+}^{-}$ & $1.5 \times 10^{2}-14$ & - \\
$\mathrm{C}_{6} \mathrm{H}_{5} \mathrm{CO}_{2}^{-}$ & $1.4 \times 10^{3}-43$ & $1.3 \times 10^{2}-8$ \\
$\mathrm{Cl}_{3} \mathrm{COO}_{2}^{-}$ & $2.8 \times 10^{3}-2.2 \times 10^{2}$ & $2.1 \times 10^{2}-6$ \\
$\mathrm{I}_{2} \mathrm{PO}_{+}^{-}$ & $1.1 \times 10^{3}-89^{*}$ & $6.8 \times 10^{2}-29$ \\
\hline
\end{tabular}



Figure 3. Changes in UV-vis spectra of 6 litraled with fluoride (as tetrabuly lammonium salt).<smiles></smiles><smiles>COP(=O)(O)ON(C(=O)NCN1CCN(CNC(=O)Nc2ccc([N+](=O)[O-])cc2)C1=O)c1ccc([N+](=O)[O-])cc1</smiles>

Figure 4. The proposed binding mode of carbosylates and dihydrogen phosphates with the receptor 6 .

6 and acetate or dihydrogenphosphate is illustrated in Figure 3.

In conclusion, we have synthesized an anion receptor based on a 2-imidazolidone molecular scaffold. Receptor 6 is selective for the oxyanions such as acetate and dihydrogenphosphate jons and the affinity for the anions simply reflects the basicity of anions.

\section{Experimental Section}

Compound 1 to a solution of 2-imidazolidone $(300 \mathrm{mg}$, $3.48 \mathrm{mmol}$ ) in DMF ( $5 \mathrm{~mL}$ ) was added paraformaldehyde
$(523 \mathrm{mg} .5 \mathrm{eq})$ and $1 \mathrm{M} \mathrm{NaOH}(0.8 \mathrm{~mL})$. The mixture was stirred for 24 hours. Evaporation of the solvent gave the product 2 in quantitative yield. 'H NMR $\left(\mathrm{CDCl}_{3}\right) \delta 4.70$ (s, $4 \mathrm{H}), 3.54(\mathrm{~s}, 4 \mathrm{H})$.

Compound 2 lo a solution of compound 1 ( $890 \mathrm{mg}, 6.1$ mmol) in pyridine $(5 \mathrm{~mL}$ ) was added acetic anhydride (3 $\mathrm{mL}$ ) and stirred for 6 hours. Evaporation of the solvent gave the product 3 in quantitative yield. ' $\mathrm{H} \mathrm{NMR}\left(\mathrm{CDCl}_{3}\right) \delta 5.29$ (s, 4H), 3.52 (s, 4H), 2.04 (s, 6H).

Compound 3 ' To a solution of compound $2(910 \mathrm{mg}, 3.95)$ in dichloromethane $(3 \mathrm{~mL}$ ) was added thionyl chloride (1 $\mathrm{mL}$ ) and stirred for an hour under nitrogen. Evaporation of the solvent gave the product 4 in quantitative yield. 'H NMR $\left(\mathrm{CDCl}_{3}\right) \delta 5.28(\mathrm{~s}, 4 \mathrm{H}), 3.56(\mathrm{~s}, 4 \mathrm{H})$.

Compound 4 to a solution of compound 3 (650 mg, 3.6 $\mathrm{mmol}$ ) in DMF (5 mL) was added sodium azide $(566 \mathrm{mg}$. 2.5 eq.) and stirred for 12 hours. After the solvent was evaporated in vacwo, chromatography of the reaction mixture on the silica gel (dichloromethane) gave the product $4(210 \mathrm{mg})$. The four step yield from the 2-imidazolidine was $30 \%$. ${ }^{1} \mathrm{H}$ NMR $\left(\mathrm{CDCl}_{3}\right) \delta 4.69(\mathrm{~s}, 4 \mathrm{H}), 3.54(\mathrm{~s}, 4 \mathrm{H}){ }^{1 .} \mathrm{C}$ NMR (DMSO-d $\left.{ }_{6}\right) \delta 158.93,60.26,41.23$. l.RMS (ГSI) calculated for $\mathrm{C}_{5} \mathrm{H}_{8} \mathrm{~N}_{8} \mathrm{O}^{+} ; 196.1$ found for 196.1.

Compound 5 lo a solution of compound 4 (40 mg) was added $\mathrm{P} d / \mathrm{C}(10 \mathrm{mg})$ and stirred for 2 hours under hydrogen. Then the reaction mixture was filtered. Evaporation of the filtered solution gave the product $5(25 \mathrm{mg})$ in $83 \%$ yield. ' $\mathrm{H}$ NMR (CDCl $) \& 4.07(\mathrm{~s}, 4 \mathrm{H}), 3.48(\mathrm{~s}, 4 \mathrm{H})$. l.RMS (ESl) calculated for $\mathrm{C}_{5} \mathrm{H}_{12} \mathrm{~N}_{4} \mathrm{O}^{-}: 144.1$ found for 144,1 .

Compound 6 [o a solution 5 (50 mg. $0.34 \mathrm{mmol})$ in dried DMF $(3 \mathrm{~mL}$ ) was added 4-nitrophenylisocyanate ( $113 \mathrm{mg}, 2$ eq.) and stirred under nitrogen. After the solvent was evaporated in vacuo, chromatography of the reaction mixture on the silica gel ( $3 \%$ methanol in dichloromethane) gave the product 6 (45 $\mathrm{mg}$ ) in $27 \%$ yield. ${ }^{1} \mathrm{H}$ NMR (DMSO-d $\mathrm{d}_{1}$ ) 89.36 $(\mathrm{s}, 2 \mathrm{H}), 8.14(\mathrm{~d}, 4 \mathrm{H}, J=10), 7.62(\mathrm{~d}, 4 \mathrm{H}, J=10), 7.07$ (s. $2 \mathrm{H}), 4.55(\mathrm{~d}, 4 \mathrm{H}), 3.34(\mathrm{~s}, 4 \mathrm{H}),{ }^{13} \mathrm{C}$ NMR (DMSO-d $\left.\mathrm{d}_{6}\right) \delta$ $159.82,154.74,146.69,140.79,125.11,117.18,48.70$. 41.45 LRMS (ESI) calculated for $\mathrm{C}_{10} \mathrm{H}_{20} \mathrm{~N}_{8} \mathrm{NaO}_{7}^{+}: 495.1$ found for 495.1 .

Compound 7 To a solution of compound 5 (140 mg. 0.97 mmol) in dried DMF (5 mL) was added 4-nitrobenzoylchloride (360 mg, $2 \mathrm{eq}$.) and stirred for 12 hours under nitrogen. After the solvent was evaporated in vacuo. chromatography of the reaction mixture on the silica gel ( $1 \%$ methanol in dichloromethane) gave the product $7(65 \mathrm{mg})$ in $13 \%$ yield ${ }^{1} \mathrm{H}$ NMR (DMSO-d $\left.{ }_{6}\right) \delta 9.36(\mathrm{t}, 2 \mathrm{H}, J=5), 8.30$ (d, 4H, $J=10), 8.11(\mathrm{~d}, 4 \mathrm{H}, J=10), 4.75(\mathrm{~d}, 4 \mathrm{H}, J=5), 3.39$ (s. 4H), ${ }^{1.3} \mathrm{C}$ NMR (DMSO-d $\left.\mathrm{d}_{\mathrm{G}}\right) \delta 165.99,159.29,149.65$, $139.84,129.43,123.96,49.12,42.05$ LRMS (ESI) calculated for $\mathrm{C}_{19} \mathrm{H}_{18} \mathrm{~N}_{6}, \mathrm{O}_{7}{ }^{+}: 442.1$ found for 442.1 .

\section{References}

1. (a) Beer. P. L.: Gale. L'. A. Angew: Chem., Int Ed. 2001. th. 486. (b) Galc. P. A. Coond Chent Rev: 2000. 199.181. (c) Snowden. T. S. Anslyn. F. V. (um Opin. (hem. Biol. 1999, 3. 740, (d) 
Antonisse. M. M. G. Reinhoudt. D. N. Chem. Commm. 1998. 443. (e) Yoon. J.: Kim. S. K.: Singh. N. J: Kim. K. S. Chemt. Soc. Rev: 2006. 35. 355 .

2. Voet. D; Voet J. G.: Pratt. C. W. Fundmentals of Biochenishy; Wiley: New York: 1999.

3. (a) Willians. D. H.: Cos, J. P: Doig. A. I. Gardner, M.: Gerhard. U.: Kaye. P. T.: Lal. A. R.: Nicholls. I. A.: Salter. C. J.: Mitchell. R. C. J. Ant Chem. Soc. 1991. 113. 7020. (b) Searle. M. S.: Williams. D. H.: Gerhard. U. J. Am. Chem. Soc. 1992. 114. 10697 .

4. (a) Szumna. A: Jurezak, I. En: J. Org Chem, 2001. 4031. (b)Hossain. M. A.: Liinares. J. M.: Powell. D: Bowman-Tames, K. Inorg Chem. 2001. 10.2936. (c) Choi. K.: Hamilton. A. D. J. An. Chem. Soc 2001. 123. 2456. (d) Hinzen. B.: Seiler. P: Diederich. F. Helv Chm. Acta 1996. 79. 942. (e) Davis. A. P: Gilmer I. F.: Perry. I. I. Angew: Chem. Int Ed. Engl. 1996. 35. 1312. (f) Sansone, F: Baldini, L.: Casnati. A.: Lazzarotto, M: Ugozzoli. F.: Ungaro. R. Proc. Katl Acad. Sci. LSA 2002. 99. 4842. (g) Andrievsky. A.: Ahuis. F.: Sessler. J. L.: Vogtle. F.: Gudat. D.: Moini. M. J. Ant Chent. Soc. 1998. 120.9712. (h) Bisson. A. P.: Lynch. V. M.: Monahan. M.K. C.: Anslyn. E. V. Angew. Chem. Wht Ed Engl. 1997.36, 2340.

5. (a) Kavallieratos. K.: Bertao, C. M.: Crabtree, R. H. J. Org. Chem. 1999, 64. 1675. (b) Kavallieratos. K.: Gala. S. R. D.: Alstin, D. J.:
Crabtree. R. H. J. Am. Chem. Soc. 1997. 119.2325. (c) Beer. P. D.: Fletcher. N. C.: Grieve. A.: Wheller. T. W.: Moore. C. P.: Wear. T. J. Chent. Soc. Perkin Trans. 2 1996. 1545.

6. (a) Gale. P. A.: Camiolo, S.: Tizzard, G. J.: Chapman, C. P.: Light. M. E: Coles, S. J.: Hursthouse. M. B. J. Org. Chem. 2001. 66 7849. (b) Gale. P. A.; Camiolo, S.; Chapman, C. P.: Light. M. E.; Hursthouse. M. B. Tetrohedhon Lett. 2001. +2.5095. (c) Canniolo. S.: Gale. P. A.: Light. M. E.:Hursthouse. M. B.: Tetrohedron Lett. 2002. +3. 6995 .

7. Zelinski, T.: Kedziorek, M: Jurezak. J. Tetrahedron Lett 2005. 46. 6231 .

8. Raposo, C:; Perez, N.; Almaraz. M; Mussons. M. L.: Caballero. M. C.: Moran. T. R. Tetrahedron Lett. 1995. 36.3255.

9. (a) Davis. A. P.: Perry. J. J.: Williams. R. P. J. Ant Chent Soc 1997. 119. 1793. (b) Ayling. A. J.: Perez-Payan. M. N.: Davis. A. P. J. Am. Chem. Soc, 2001, 123, 12716.

10. Valivaveetil. S:- Engbersen. J. F. J:- Verboom. W. Reinhoudt. D. N. Angew. Chem. Int. Ed Engl. 1993. 32, 900.

11. (a) Matthews. S. E.: Beer. P. D. Supranol. Chent 2005. 17. 411. (b) Lhoták. P. Top Curr. Chem. 2005. 255. 65. (c) Beer. P. D.: Timoshenko. V: Maestri. M.: Passaiti. P.: Balzani. V. Chent. Conm. 1999. 1755

12. Hynes. M. J. J. Chem. Soc. Dalton Trans. 1993, 311.

13. Benesi, H.: Hildebrand. H. J. Am. Chem. Soc. 1949, 71. 2703. 